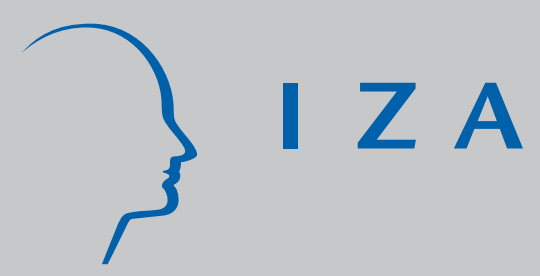

IZA DP No. 276

The Impact of Product Market Competition on Employment and Wages

Bruno Amable

Donatella Gatti

March 2001 


\title{
The Impact of Product Market Competition on Employment and Wages
}

\author{
Bruno Amable \\ University of Lille and CEPREMAP \\ Donatella Gatti \\ Wissenschaftszentrum für Sozialforschung Berlin (WZB) \\ Discussion Paper No. 276 \\ March 2001 \\ IZA \\ P.O. Box 7240 \\ D-53072 Bonn \\ Germany \\ Tel.: +49-228-3894-0 \\ Fax: +49-228-3894-210 \\ Email: iza@iza.org
}

This Discussion Paper is issued within the framework of IZA's research area The Future of Work. Any opinions expressed here are those of the author(s) and not those of the institute. Research disseminated by IZA may include views on policy, but the institute itself takes no institutional policy positions.

The Institute for the Study of Labor (IZA) in Bonn is a local and virtual international research center and a place of communication between science, politics and business. IZA is an independent, nonprofit limited liability company (Gesellschaft mit beschränkter Haftung) supported by the Deutsche Post AG. The center is associated with the University of Bonn and offers a stimulating research environment through its research networks, research support, and visitors and doctoral programs. IZA engages in (i) original and internationally competitive research in all fields of labor economics, (ii) development of policy concepts, and (iii) dissemination of research results and concepts to the interested public. The current research program deals with (1) mobility and flexibility of labor markets, (2) internationalization of labor markets and European integration, (3) the welfare state and labor markets, (4) labor markets in transition, (5) the future of work, (6) project evaluation and (7) general labor economics.

IZA Discussion Papers often represent preliminary work and are circulated to encourage discussion. Citation of such a paper should account for its provisional character. 
IZA Discussion Paper No. 276

March 2001

\section{ABSTRACT \\ The Impact of Product Market Competition on Employment and Wages*}

Standard economic wisdom generally stresses the benefits of increased competition on the product market. This paper proposes a model of monopolistic competition with an endogenous determination of workers flows in and out of unemployment, where wages are determined according to an efficiency wage mechanism. We show that an increase in product market competition boosts the hiring rate as well as the separation rate. Hence, the efficiency wage schedule compatible with more competition shifts upward. An adverse effect on workers' incentive is at work which pushes real wages up to the point that increased competition may indeed generate employment losses rather than gains.

JEL Classification: E24, J41, J63, L13

Keywords: Unemployment, efficiency wage, imperfect competition

Donatella Gatti

Social Science Research Center (WZB)

Reichpietschufer 50

10785 Berlin

Germany

Tel. +493025491117

Fax + 493025491480

Email: gatti@medea.wz-berlin.de

\footnotetext{
* The authors thank Torben Andersen, Michael Burda, Juan Dolado, Michael Pflüger, Robert Solow, Dennis Snower, Christian Bidard and David Soskice for helpful remarks on this and previous versions of the paper. Comments by participants to the Winter Meeting of the Econometric Society (January 2001, New Orleans), the IZA Workshop on International Integration and European Labour Markets (December 2000, Bonn), the CEPR-IZA European Summer Symposium in Labour Economics (October 2000, Ammersee), the séminaire du MODEM (October 2000, Nanterre) the EEA Conference (September 2000, Bolzano) and the T2M Workshops (May 2000, University of Nanterre) are also gratefully acknowledged. The usual caveats apply.
} 


\section{Introduction}

T he detrimental inłuence of labour market imperfections on employ ment performance has long been emphasized in the literature ${ }^{1}$ and has led to a large set of policy recommendations in favor of labour market reforms. A recent literature has more speci..cally focused on the interactions between imperfections in the labour and the product markets. ${ }^{2}$ The basic idea is that imperfections in one market combine with those of the other markets to make matters worse in each of them. A s a consequence for economic policy, labour market reforms should be accompanied by reforms on the product markets, the latter being expected to all eviate the burden of adjustments on the labour market thus favouring employment. ${ }^{3}$

The channels of positive interaction between product market competition and employment are clearly spelled out for instance in Nickell [1999]. First, an increase in product market competition will augment output and shift out labour demand curves, bringing about an increase in ..rms' labour demand for any given wage level. The positive exect, i.e. the external shift of the labour demand curve, derives from the modi..cation of ...rms' pricing behaviour when competition becomes stronger. The rationale is straightforward: higher competition reduces market power for each ..rm, this lowers the price mark-up that ..rms are ableto enforce, and increases employment at any given level of real wages. This ..rst exect is clearly positive, however the ..nal

\footnotetext{
${ }^{1}$ Se for inst ance Layard et al. [1991], Nickell [1997], Siebert [1997].

${ }^{2}$ B oeri et al. [2000], Nickell [1999], Nicoletti et al. [2000], Gersbach [1999] and [2000].

${ }^{3}$ International organizations such as the OECD have advocated the implementation of structural reforms both in the labor and the product markets, towards more fexibility regarding wages and employment protection on the one hand, and the promotion of competition on the product markets by regulatory reform on the other side (see OECD [1994], Nicoletti et al. [2000]).
} 
outcome in terms of employment and wages depends on the response stemming from the wage setting process.

This observation stresses the need for an analysis of the wage setting behaviour and leads to the second positive exect put forward by Nickell: more competition on the product market being associated with a decreasing elasticity of labour demand, this lowers the bargained real wage schedule. The main reason for this is the following: when the labour demand elasticity becomes higher, the negative impact on both employment and pro..ts of any increase in wages is larger; this reduces unions' claims and the bargained level of the real wage. ${ }^{4}$ Hence, the author concludes that single unionised ..rms which face increased competition will bene..t from a higher labour demand elasticity and a lower bargained real wage schedule: the ..nal outcome of increased competition is therefore higher employment possibly combined with higher real wages.

Empirical results on the impact, at the aggregate level, of increased competition on labour markets and employment are provided by recent contributions such as B oeri et al. [2000] and Nicoletti et al. [2000]. B oth papers are based on a new OE CD index of product market regulation which proves to be strongly correlated to dixerent measures of labour market regulation. Interestingly enough, the only measure of product market (de)regulation that is not correlated with labour market (de)regulation (that is the outward-oriented regulation - trade and investment barriers) generates a positive impact on wages and a negative impact on employment. As a consequence of the

\footnotetext{
${ }^{4}$ Se Layard, Nickell and J ackman [1991], Nickell et al. [1994] and Nickell [1999].
} 
correlation between product and labour market reforms $\left({ }^{5}\right)$, the outcome in terms of employment should consider both the direct exect of product market reforms on employment (for instance, via lower market power and mark-up) as well as the indirect exects on labour market operation, the latter exect being possibly negative as shown for instance in the literature on turnover and job security (see Bertola [1990]).

Nickell [1999] does provide a theoretical intuition of a possible relation between workers turnover and wage formation which passes through the "..Iter" of product market competition: the author suggests that reduced labour demand elasticity (associated with market power) may induce stronger rent capture (by insiders) and higher retention rates; this increases job security for any given level of wages. The overall outcome would then be a higher bargained real wage schedule.

The idea that increased competition on the product market may be associated with stronger turnover on the labour market puts forward the tight links between the operation of product and labour markets which are also stressed by Boeri et al. [2000] and Nicoletti et al. [2000]. Moreover, according to these two contributions, product market competition would be stronger in economies such as the US and UK, which would then be coherent with the fact that workers łows are stronger in those two countries and that retention and tenure are higher in continental Europe as well as in J apan (see OE CD [1994] and [1997]) $\left({ }^{6}\right)$.

In spite of this, Nickell's argument that increased competition reduces job secu-

\footnotetext{
${ }^{5} \mathrm{~A}$ ndersen [2000] proposes a model which suggests that product marker integration may indeed reduce workers' market power thus changing labour market structure by acting as an implicit labout market reform.

${ }^{6} \mathrm{~T}$ he evidence on this point is indeed mixed. B ertola and R ogerson [1997] and B urda and $W$ yplosz [1994] suggest that job (and to some extent, workers) ‡ows are similar across the US and Europe.
} 
rity and wages, thus favouring employment, implies on the one side that a negative correlation exists between product market competition and wages, and on the other side that job security is associated with higher real wages. However, the evidence in this regard is at best mixed: concerning the latter, Bertola [1990] shows for instance that job security provision yields no negative impact on employment and is indeed associated with lower aggregate real wages; ${ }^{7}$ as for competition and wages, Nickell [1999] reports that a negative correlation only shows on micro- and industry data from unionized .r.rms, while such a correlation cannot be observed for non unionized ..rms. This suggests that the impact of competition and turnover on wages (and employment) is indeed sensitive to the nature of the prevailing wage setting mechanism.

A perverse impact of turnover on employment emerges for instance in two recent papers addressing the relation between turnover, wages and employment under theassumption of perfect competition on the product markets. Snower and Diaz-Vazquez [1996] develop a model of wage bargaining and macroeconomic ¥uctuations which shows that stronger turnover (i.e. lower ..ring and hiring costs) can lead to perverse employment consequences when $\ddagger$ uctuations are transient and union power moderate. Fella [2000] investigates this issue in an ed ciency wage framework and shows that redundancy pay may exercise a positive exect on welfare by reducing the (suboptimally) high rate of turnover determined by employment decisions of individual ..rms in the presence of intertemporal externalities; this paper also shows that increased job security actually reduces the level of the (ed ciency) wages at the equilibrium.

\footnotetext{
${ }^{7}$ However, Lazear [1990] provides evidence of a negative impact of dismissal regulation on employment levels.
} 
Our model builds on this intuition and addresses the impact of product market competition on turnover, wages and employment, in an eфc ciency wage framework. In this respect, $\mathrm{N}$ ickell [1999] notes that eł ciency wages generally depend on 'exogenous' factors such as: external opportunities, monitoring technologies, quit and turnover functions. He therefore submits that "in none of these cases does there appear to be any obvious mechanism by which the market power of the ..rm can enter the story" (p. 7). This conclusion is indeed misleading. In fact, we will show that a mechanism exists which links up the market power of ..rms to the ed ciency wage premium by endogenising labour market turnover following demand or productivity shocks.

To address the issue, this paper proposes a model of monopolistic competition where ..rms endogenously determine workers łows in and out of unemployment by setting wages according to an eф ciency wage mechanism. M ore precisely, we assume that ..rms move across two dixerent states of technology: Good (type-G) and B ad (type-B ). When moving, they respectively hire and ..re workers thus generating a certain turnover on the labour market. Workers have to be indixerent across the two options of working in ...ring (formerly type-G ..rms experiencing a B ad shock) or hiring (formerly type-B ..rms experiencing a Good shock) ..rms, which generates a positive wage dixerential across ..rms in dixerent states. At the same time, due to the monopolistic competition assumption, productivity dixerentials across ..rms are (partially) translated into price dixerentials across type-B and type-G ..rms: this contributes to smoothing employment dixerentials across ..rms in dixerent states, thus reducing the size of workers $\ddagger$ ows as a response to demand and/ or productivity shocks. 
In this setup, increased competition (that is a higher elasticity of demand) clearly compresses price dixerentials and consequently leads, due to real wage rigi dities stemming from theed ciency wage setting, to larger employment dixerentials across type-G and type-B ..rms. The rationale is that stronger competition on the product market means that relative prices tend to approach unity. Hence, as competition increases ..rms are increasingly forced to adjust to shocks through quantities' adjustments rather than through price adjustments. As a consequence, under stronger competition ..rms modify employment in response to shocks more than they would under weak competition. As more competition exacerbates the dixerential in employment levels existing across type-G and type-B ..rms, more separations as well as hiring are generated as response to shocks: this unambiguously rises turnover on the labour market. 8

Two are the main consequences of this mechanism. First, the wage premium paid by potentially ..ring ..rms always rises with respect to the premium paid by hiring ..rms, which may lead to rising relative wages. Second, due to the impact of turnover on ed ciency wages premia, an adverse exect on workers' incentives is in place which generates wage pressure and may ultimately result in a higher level of unemployment.

The paper is organised as follows. Section 2 below presents the basic model of eф ciency wage and imperfect competition on the product markets. Section 3 presents the macroeconomic equilibrium, which is shown to be unique in certain conditions. section 4 establishes the result that an increase in product market competition may lead to a lower performance in terms of employment. Section 5 brieły concludes.

\footnotetext{
${ }^{8} \mathrm{~T}$ his result is consistent with empirical evidence on industry data provided by Weiss [1998].
} 


\section{The model}

We assume the existence of a multi-sector economy with a single ..nal good used for consumption and a continuum of intermediate goods indexed over [0; 1]. The ..nal good is produced according to a constant returns to scale technology using all the intermediate goods:

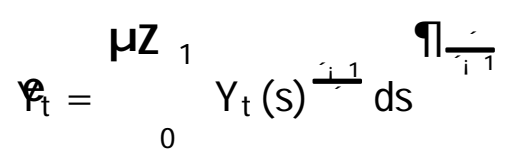

$>1$ is the absolute value of the elasticity of substitution between intermediates. The ..nal good is produced competitively, but there is imperfect competition in each of the intermediate sectors. M ore speci..cally, it is assumed that there is only one ..rm in each intermediate sector ${ }^{9}$. Each ..rm is small compared to the economy but has a monopoly power within its sector. Such a speci..cation leads to a derived demand addressed to sector s equal to:

$$
Y_{s}=\frac{\mu_{P_{s}}}{P} I_{i}^{\prime}
$$

where $P_{s}$ is the price of intermediate $s$ and $P$ is the ..nal good's price. One further has:

$$
P=\int_{0}^{\mu Z_{1}} P_{s}^{1_{i}{ }^{\prime}} d s^{\prod \frac{1}{1 i}}
$$

Each ..rm j in every sector $\mathrm{s}$ has an identical production function which uses

\footnotetext{
${ }^{9} \mathrm{~T}$ his assumptions is not crucial to our results. We could alternatively assume $\mathrm{C}$ ou rnot competition in each intermediate sector and study the consequence of free entry (increase in $n$ ). This would not axect our results but would make things a bit more complicated. That is why we have preferred to stick to the simplifying assumption of monopolistic competition.
} 
labour as its sole input :

$$
y_{j t}=\otimes_{t} \phi l_{j t}
$$

$0<{ }^{0} \quad 1, l_{j}$ is the input of exective labour, i.e. $l_{j}$ workers providing the expected exort level. Firms are subject to 'productivity' shocks which can be thought as stemming from $\ddagger$ uctuations in factors other than labour or from a varying technological eł ciency. We adopt the same shock speci...cation as B ertola [1990], B ertola and Ichino [1995] or Bertola and Rogerson [1997]. The shock's realisations are denoted $\otimes_{\mathrm{t}}$ for ..rm j at time t, they are independent across ..rms. More speci..cally, the ${ }^{\circledR} \mathrm{s}$ follow a two-state Markov chain with symmetric transition probability $\mathrm{p}$ :

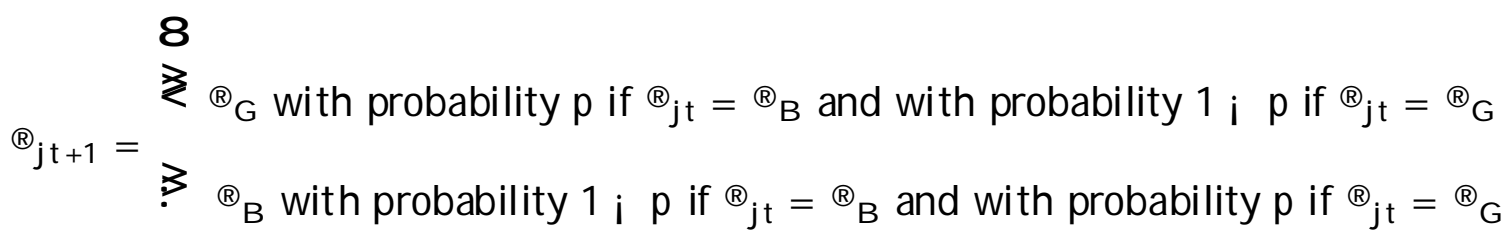

and $\AA_{G}>\mathbb{B}_{B}>0$. We further assume some degree of 'persistence' in the shocks' realisation: $p<1=2$.

There are thus two states for the technology: a 'good' state $G$ with a high labour productivity, and a 'bad' state B with a low value for labour productivity. The longrun probability for a given ..rm to be in either a good or a bad state is $0: 5$. In what follows, we will then assume that at each timet, $50 \%$ of the ..rms are in the good state while $50 \%$ are in a bad state ${ }^{10}$. Therefore, there will be no aggregate łuctuations in either output or employment.

\footnotetext{
${ }^{10} \mathrm{~W}$ e assume that the number of ..rms is large enough. This also means that ..rms will not consider the impact on the aggregate price index, when maximising pro..ts.
} 


\section{1 wage setting}

The economy is populated with a ..xed number $\mathrm{N}$ of agents who supply labour inelastically. Each individual worker is characterised by an identical utility function, where instantaneous utility depends on the real wage ${ }^{11}$ and on the ex ort provided on the job:

$$
u_{t}=w_{t}^{j} ; \quad e_{t}
$$

$j=G ; B ; e_{t}$, the exort level, can take two values, 0 , which means that the worker is 'shirking' and e, which means that the worker provides the expected work exort. The contribution of a shirker to exective labour is nil, whereas an individual working with the expected exort level e contributes for one unit to exective labour. $w_{t}^{j}$ is the real wage. This simple speci..cation and will allow us to consider an eф ciency wage model in the spirit of Solow [1979], Shapiro and Stiglitz [1984], A kerlof and Y ellen [1990] or Saint-Paul [1996]. The basic principle of these models is that a ..rm may not wish to lower wages even in the presence of unemployment for fear of reducing the incentives to provide the correct level of exort on the job. Each ..rm has a monitoring device whose inet ciency is measured by the parameter $\mathrm{x}_{\mathrm{t}}$ : A worker is caught shirking with probability $x_{t}$ and, when caught, loses his job at the end of period t. The probability of getting away with shirking is thus $1 \mathrm{i} \mathrm{x}_{\mathrm{t}}$.

But, as is common in et ciency wage models, shirking is not the only way to lose one's job. Every model of eł ciency wage takes into account an independent and

\footnotetext{
${ }^{11}$ i.e. the consumption level of the ..nal good.
} 
exogenous probability of job loss. In our setting, this probability is made endogenous: ..rms are subject to shocks which axect their productivity in a way that will be shown in the next section. As a consequence, ..rms shed labour when they are hit by an adverse shock which forces them to downward adjust their labour force. If $I_{G}\left(I_{B}\right)$ is employment of a representative ..rm in a good (bad) state and we denote $q_{t}$ the probability of losing one's job following an adverse shock, then:

$$
q_{t}=\frac{I_{G t} i I_{B t}}{I_{G t}}=1 i \frac{1}{I_{t}}
$$

with $I=\frac{I_{G t}}{I_{B} t}$ :

Only workers inside a type-G ..rm are concerned by this type of job loss since only type-G ..rms are likely to be hit by an adverse shocks. The situation of type-B ..rms can only improve or at worst stay the same. At each time, a certain proportion ${ }^{12}$ of type-G ..rms is hit by an adverse shock and has to shed labour, whereas some type-B ..rms enjoy a favourable shock and have to hire workers out of the pool of unemployed in order to adjust their labour force. Workers having lost their job become unemployed: we will assume that there is no unemployment allowance. The ‡ow probability out of unemployment is $a_{t}$, which is the probability for an unemployed of ..nding a job ${ }^{13}$.

As in Fella [2000], we assume that workers have an in..nite horizon and discount future at the rater. We can now compute the discounted utilities associated with the

\footnotetext{
${ }^{12} \mathrm{~A}$ proportion $\mathrm{p}$ when one applies the law of large numbers.

${ }^{13} \mathrm{~T}$ his probability is also endogenous and will be determined at the equilibrium by a łow equilibrium condition, as shown in section 3.
} 
various possible positions for an individual: being employed in a type; $G$ or a type-B ..rm and shirking or not shirking, or being unemployed. The discounted utility of a worker who shirks at time $t$ in a type-G..rm is $V_{S t}^{G}$, and $V_{N S t}^{G}$ when he does not shirk. The utilities associated to working in a type ..rm are likewise $V_{S t}^{B}$ (shirking) and $V_{N S t}^{B}$ (not shirking). The utility of being unemployed is $U_{t}$. We then have:

$$
\begin{aligned}
& r \phi U_{t}=a \phi^{i} V_{t}^{G} i U_{t}{ }^{\phi} \\
& r \phi V_{S t}^{G}=w_{t}^{G}+(x+p \phi q) \phi^{i} U_{t} i V_{S t}^{G}{ }^{\Phi}+p \phi(1 ; \quad q) \phi^{i} V_{t}^{B} ; V_{S t}^{G}{ }^{\Phi} \\
& r \nsubseteq V_{N S t}^{G}=w_{t}^{G} i \quad e+p \notin q \phi^{i} U_{t} i V_{N S t}^{G}{ }^{\Phi}+p \Phi(1 ; \quad q) \phi^{i} V_{t}^{B} i V_{N S t}^{G}{ }^{\phi} \\
& r \notin V_{S t}^{B}=w_{t}^{B}+x \phi^{i} U_{t} i V_{S t}^{B}{ }^{\Phi}+p \phi^{i} V_{t}^{G} i V_{S t}^{B}{ }^{\phi} \\
& r \notin V_{N S t}^{B}=w_{t}^{B} i \quad e+p \phi^{i} V_{t}^{G} i V_{N S t}^{B} \Phi
\end{aligned}
$$

$V_{t}^{B}$ and $V_{t}^{G}$ are equilibrium levels associated with working in a $B i$..rm and in a $\mathrm{G}_{\mathbf{i}} . . \mathrm{rm}$ respectively.

The level of real wage in each ..rm must be set at a level such that workers have an incentive not to shirk. These no-shirking conditions are

$$
V_{N S t}^{j}, V_{S t}^{j}
$$

$T$ he conditions $V_{N S t}^{j}=V_{S t}^{j}=V_{t}^{j}, j=G ; B$ give thetwo limit wagelevels $w_{i t}^{G}{ }^{i} w_{i t}^{B}{ }^{\phi} ; w_{i t}^{B}{ }^{i} w_{i t}^{G}{ }^{\phi}$ under which the optimal behaviour for the worker is to shirk. Since we are dealing with constant values for all variables at the steady-state equilibrium, we may dispense with the time subscripts from now on. Both $w_{i}^{G}{ }^{i} w_{i}^{B}{ }^{\Phi}$ and $w_{t}^{B}{ }^{i} w_{i}^{G}{ }^{\Phi}$ are aф ne functions.

By imposing the no-shirking conditions, one obtains: 


$$
\begin{aligned}
& V_{S}^{G}=V_{N S}^{G} ! x \Phi^{i} U_{t} i V^{G}{ }^{\Phi}=i e \\
& V_{S}^{B}=V_{N S}^{B} ! x \pitchfork^{i} U_{t} i^{B}{ }^{\Phi}=i e
\end{aligned}
$$

from which one can easily see that the following arbitrage condition always holds at the equilibrium:

$$
V^{G}=V^{B}
$$

which ensures that workers are indixerent between working in a type-G ..rm and working in a type-B ..rm. From these conditions, one may deduce the following proposition:

Proposition 2 Real wages in type-G ..rms are always higher than real wages in typeB ..rms. The wage-premium increases with the probability of experiencing a bad shock $p$ and is independent of the realisations of the shocks.

Proof. Condition (9) gives a relationship between the wage in a type $G$.r.m and that in a type ..rm:

$$
w_{G}=w_{e}^{G}\left(w_{B}\right)=\frac{(a+r+p \phi q) \phi w_{B} ; p \phi q}{a+r}
$$

The incentive conditions for each type ..rms give two relationships, $w_{i}^{G}{ }^{i} w^{B}{ }^{\Phi}$ and $w_{i}^{B}{ }^{i} w^{G}{ }^{\Phi}$. Solving $w_{e}^{G}\left(w_{B}\right)=w_{i}^{G}{ }^{i} w^{B}{ }^{\Phi}$ and plugging into $w_{i}^{B}{ }^{i} w^{G}{ }^{\Phi}$ give the equilibrium values for $w^{B}$ and $w^{G}$ :

$$
\begin{aligned}
& w^{G}=\frac{a+p \phi q+r+x}{x} \\
& w^{B}=\frac{a+r+x}{x}
\end{aligned}
$$


The el ciency wage paid by either type of ..rms is higher the higher the hiring rate is. The justi..cation for this result is simple. When the hiring rate increases, shirkers caught (and ..red) will have a higher probability of ..nding new employment in a type-G ..rm. Therefore, a shirker's utility increases and a compensation in the form of a higher wage is required in order to enforce the no-shirking condition. A higher separation rate will have the consequence of raising wages in type-G ..rms. Workers can be ..red regardless of their exort when the ..rm employing them is hit by a bad shock. E very employed worker has then to face the possibility of losing his position. This possibility is all the more plausible that the separation rate is high; thus a higher separation rate reduces the discounted utility associated to a no-shirking strategy, which calls for a higher eф ciency wage (potentially) ..ring ..rms.

\section{2 labour demand}

To de. ne ..rms' hiring decisions across sectors one should consider that wages are set by type-G and type-B ..rms at the minimum level which respects the exortincentive constraint for workers; every worker then provides the necessary exort so that exective and employed labour are equal. Since the value of the el ciency wage for type-G..rms depends on the separation rate $q=1 ; \frac{1}{1}$, pro.t. maximisation for 
..rm j in any intermediate sector gives: 14

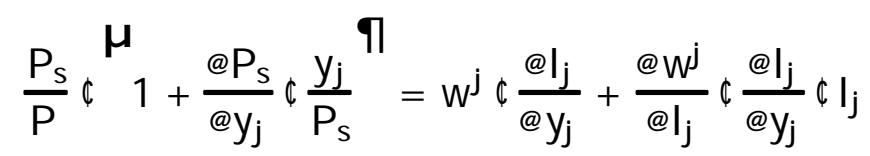

$w_{j}$ is the real wage paid by ...rm j . The term $\frac{a^{j}}{\varliminf_{j}}$ captures the impact of ..rms' labour demand on the relative employment level and thus on the separation rate; this axects the ed ciency wage level for type-G ..rms. One should further note that $w^{B}$ only depends on the hiring rate (the average variable a) and therefore $\frac{@_{\mathrm{B}}^{\mathrm{B}}}{\varliminf_{\mathrm{B}}}=0$.

B ecause ..rms have market power within their sector, the price of intermediate vary across type $G$ and type $B$.r.ms: we denote it respectively $P_{G}$ and $P_{B}$. A ssuming for simplicity $P=1$, we can rewrite (12) as follows:

$$
\begin{aligned}
& \mathrm{P}_{\mathrm{G}} \leftarrow_{\mu}^{\mu} 1 i^{\frac{1}{q}}=\frac{w^{G}}{\mathbb{R}_{G}}+p \phi \frac{1 ; q}{x \phi \mathbb{R}_{G}} \\
& P_{B} \oplus 1 ; \frac{1}{\tau}^{9}=\frac{w^{B}}{\mathbb{R}_{B}}
\end{aligned}
$$

The two price setting equations relate the price of intermediate goods (relative to the price index P ) to the real wage level in each sector of the economy. From the price index (3) and aggregate production (1), one can derive the expression for intermediate goods' prices. We can denote $Y_{B}$ as total output of ...rms in a bad state and $Y_{G}$ is total output of ..rms in a good state; likewise employment is respectively given by $L_{B}$ and $L_{G}$. As within the economy at any given time, there will be half of

\footnotetext{
${ }^{14} \mathrm{~T}$ he maximisation is state-contingent. It could be written in its intertemporal form as follows:

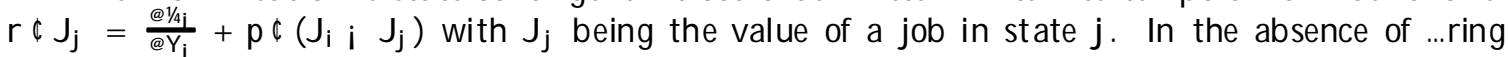
and hiring costs, ..rms will hire and ..re workers so as to ensure $\mathrm{J}_{\mathrm{j}}=0$. This gives the condition presented in the text.
} 
the ..rms in a bad state and half of the ..rms in a good state, from (1) one obtains that:

$$
\begin{aligned}
& \varphi_{t}={ }^{3} R_{1} Y_{t}(s)-1 \text { ds }{ }^{\prime}{ }^{\prime}{ }^{\prime}
\end{aligned}
$$

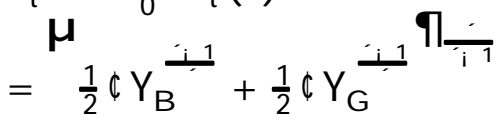

Since $Y_{S}=P_{S^{i}}{ }^{\prime} \Psi$, de..ning ${ }^{\circledR}=\frac{\Theta_{G}}{\Theta_{B}}$ one has:

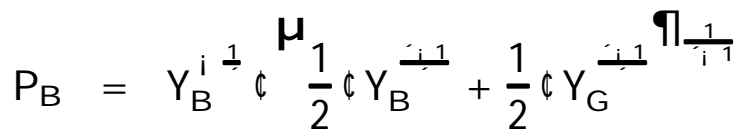

$$
\begin{aligned}
& =\frac{\tilde{A}}{1+(\circledast \phi)+1} \frac{1}{2} \frac{1}{i 1}
\end{aligned}
$$

and:

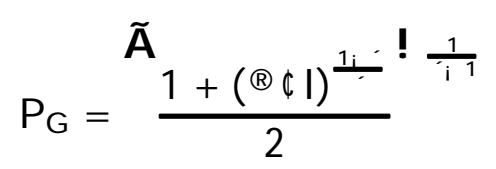

$M$ oreover, an expression for the relative price of intermediates $\frac{P_{B}}{P_{G}}$ can also be derived from the demand curves (2). One easily obtains:

$$
\frac{P_{B}}{P_{G}}={ }^{\mu_{Y_{G}}}{ }_{Y_{B}}^{\eta_{1}}=(\circledast Q \mid)^{-}
$$

Firms in the intermediate sectors earn positive pro..ts at the equilibrium. However, these pro..ts clearly vanish as competition increases that is as the price elasticity of demand within each industry rises (we will come to this point in section 4). ${ }^{15}$

\footnotetext{
${ }^{15} \mathrm{O}$ ne should further note that the set-up of the model implies pro..ts and wages being entirely spent in consumption of the ..nal (competitive) good.
} 


\section{Macroeconomic equilibrium}

At any instant $t$, half of the ..rms in every intermediate sector experience a favourable shock while the other half experience a bad shock: a fraction $p$ of the type-G ..rms switch positions with a fraction $p$ of the type-B ..rms. The formerly type-G turned type-B ..rms have to shed labour in order to adjust their labour force to its optimal value, while formerly type-B now type-G ..rms need to makethe opp osite adjustment. Laid-ox workers join the ranks of the unemployed while some unemployed workers ..nd new employment with .r.ms having switched from B to G. At the steady state equilibrium, the unemployment rate stays constant and the fows in and out of unemployment balance each other out. Recalling that $a$ is the fow probability out of unemployment, one has:

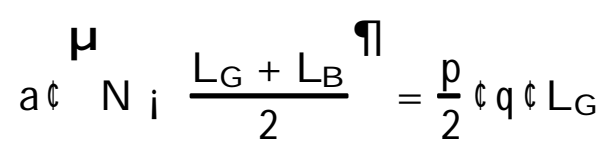

Since we know that $q=1 ; \frac{1}{1},(17)$ allows us to de.ne aggregate employment as a function of the separation and hiring rates. Hence, we can solve the model by deriving the equilibrium values of the latter two endogenous variables. To do that, we shall show that the price setting equations (13) taken together de. ne the equilibrium value of the employment ratio of type-G to type-B ..rms as well as the hiring rate. This will allow us to de..ne the level of employment and wages in ..rms of either type.

First, it must be observed that combing the two price setting equations (13), one has

$$
\frac{P_{B}}{P_{G}}=\frac{\circledR C W^{B}}{{ }^{\prime} G}
$$


with ' ${ }_{G}=w^{G}+p \frac{l_{i} g}{x}$ : Then, using (16) to substitute for $\frac{P_{B}}{P_{G}}$ and (11) to substitute for $W_{B}$ and ' $G$, one can easily rewrite the condition above, to obtain $\frac{(a+r+x) \notin B}{a+p+r+x}=$ $(\circledR \bigotimes \mid)^{-1}$ : T his de. nes a ..rst expression for relative employment I that we denote:

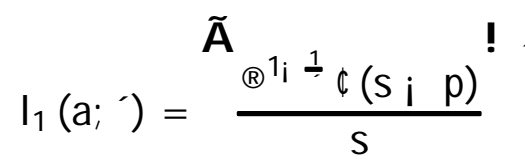

where to simplify notations, we use the variable $s^{\prime} a+x+r+p$ which is a simple linear transformation of the endogenous variable a. One can show that $\frac{\Phi_{1}}{\Subset s}>0$, $\frac{\Phi_{1}}{\Theta}>0$.

To de..ne the equilibrium solution, a second expression for relative employment can be derived from (13). In fact, we shall note that (13) ensures $\mathrm{P}_{\mathrm{G}} \$ 1 \mathrm{i} \frac{1}{\frac{1}{1}}=\frac{\mathrm{C}}{\mathbb{B}_{\mathrm{G}}}$ : Substituting (15) for $P_{G}$ and using the value of ed ciency wage to replace for ' ${ }_{G}$; one obtains:

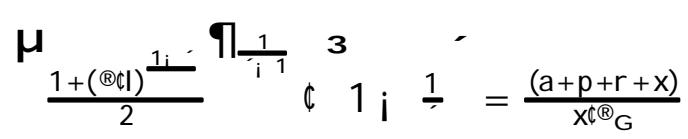

from which the following expression for relative employment I can be derived:

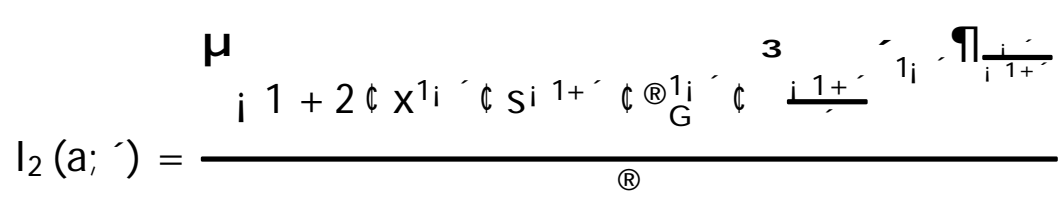

One can show that $\frac{\Phi_{2}}{\Theta}>0$ and $\frac{\Phi_{2}}{\Theta}<0^{16}$.

Therationale for these results is the following. Take, for instance, the relative price

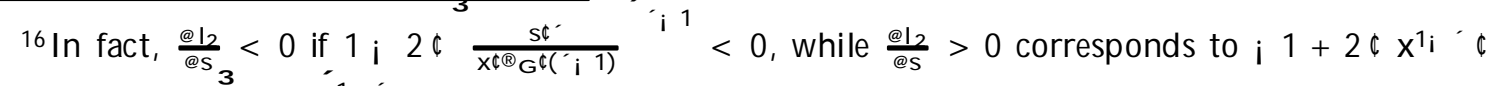

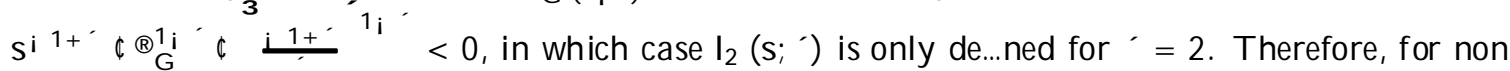
complex solutions of $\mathrm{I}_{2}\left(\mathrm{~s}^{\prime}{ }^{\prime}\right)$, one has $\frac{\mathrm{d}_{2}}{\Theta_{s}}<0$.
} 
equilibrium condition (18) which generates $I_{1}\left(a ;{ }^{\prime}\right)$. The ratio of the intermediate goods' prices $\frac{P_{B}}{P_{G}}$ being a function of the relative demand for intermediate goods and thus of relative employment I, a higher value of ' has the consequence of compressing relative prices towards unity thus producing an increase in I for any given level of wages. On the other hand, a higher value of the endogenous variable a pushes the labour costs ratio $\frac{\mathbb{\Omega}^{B} \mathrm{~B}}{\mathrm{G}}$ up and lowers the demand for labour from type-B ...rms relative to type G ..rms; hence, the increase in I. This explains the sign of the derivatives of $I_{1}\left(a ;{ }^{\prime}\right)$ with respect to $a$ and '. Similar arguments can then be proposed as regards the $I_{2}\left(a ;{ }^{\prime}\right)$ function.

The equilibrium can now be deduced from the condition:

$$
I_{1}\left(a ;{ }^{\prime}\right)=I_{2}\left(a ;{ }^{\prime}\right)
$$

which leads us to the following prop osition.

P roposition 3 There exists a unique equilibrium for the model if

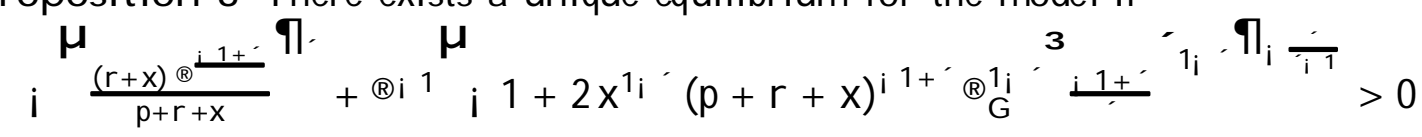

and

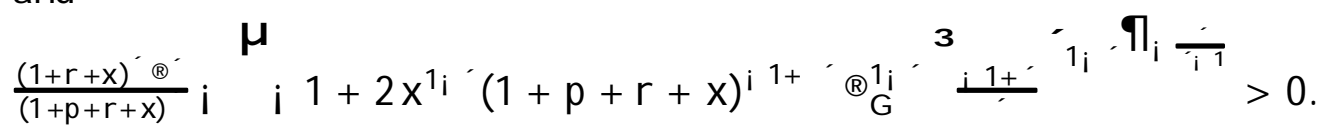

Proof. The ..rst condition ensures that $I_{2}\left(0 ;{ }^{\prime}\right)>I_{1}\left(0 ;{ }^{\prime}\right)$, and the second that $I_{2}\left(1 ;{ }^{\prime}\right)<I_{1}\left(1 ;{ }^{\prime}\right) . I_{2}\left(a ;{ }^{\prime}\right)$ being a decreasing function of $a, I_{1}\left(a ;{ }^{\prime}\right)$ an increasing function, there exists a unique a 2 ]0; $1\left[\right.$. Since $s^{\prime} a+x+r+p$; the solution for $a^{x}$ is identi..ed by the value of $s$ which solves the following equality: $\frac{s}{s_{i} p} \phi \frac{1}{{ }^{3}}{ }^{\prime} i 1=$

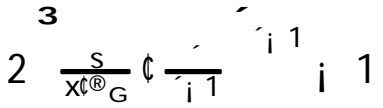


Hence, we have by now established su $\phi$ cient conditions for the existence of a unique equilibrium to which is associated a certain level for real wages and unemployment. This result has been derived given a certain degree of imperfection in product market competition, i.e. a certain value of the price elasticity of demand that monopolistic ..rms are facing. Building on this, we can now move on to the analysis of the macroeconomic consequences of an increase in competition on the product market.

\section{The consequences of an increased competition on the product market}

This section investigates the consequences of an increase in the price elasticity of demand within each industry. In our model, imperfections in competition vanish when this elasticity goes to in..nity. The price elasticity of demand may be considered as a policy variable or at least inłuenced by competition policy measures. In some industries in most countries, ..rms' entry is de facto if not de jure restricted, making market structures oligopolist: some of these restrictions are the consequences of international dixerences in regulations, norms or other administrative matters that make cross-border competition more diф cult that competition between domestic ..rms. The elimination of such barriers to competition was the aim of the Single E uropean M arket completion for instance

In this model, the exects of an increase in product market competition cannot just be read ox the shift in the labour demand curve. The consequences in terms 
of wage-setting behaviour have to be taken into account too. One determinant of the ed ciency wage is job turnover, which is function of the hiring rate a and of the separation rate q. Ceteris paribus a decrease in job security and/or in unemployment duration leads to an increase in the ec ciency wage. A ..rst result concerning the exect of product market competition on job turnover is established in the following proposition.

P roposition 4 An increase in ' always raises the separation rate

Proof. Since $q=1 ; \frac{1}{1}$, the result immediately derives from the shifts of the $I_{1}\left(a ;{ }^{\prime}\right)$ and $I_{2}\left(a ;{ }^{\prime}\right)$ curves when competition increases. This can easily be seen in Fig. 1 below.

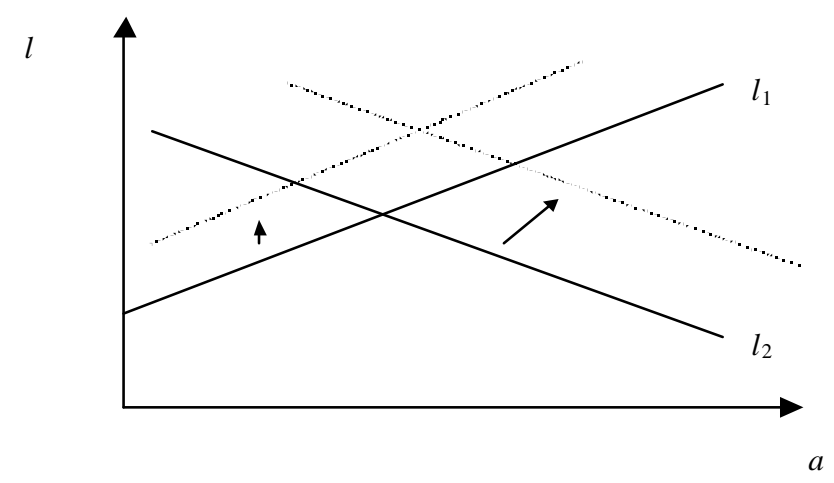

Figure 1. The exect of increased competition on I

A nother way to prove the result is the following. Consider that $\frac{d l}{d{ }^{\prime}}=\frac{\Phi_{1}}{\Phi_{0}}+\frac{d_{1}}{\Phi_{a}} \frac{d a}{d^{\prime}}=$

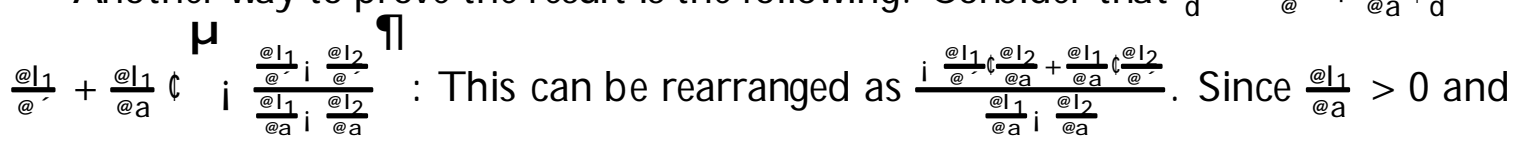
$\frac{\Phi_{2}}{\Theta}<0$, the result immediately follows from the fact that $\frac{\Phi_{1}}{\varrho}>0$ and $\frac{\Phi_{2}}{\varrho}>0$ :

This proposition establishes that an increase in product market competition leads to an decrease in job security. The immediately leads us to the following corollary. 
Corollary $5 \mathrm{An}$ increase in ' raises the wage diæerential between ...ring and hiring .rms

Proof. This result simply derives from $w^{G} ; w^{B}=\frac{a+p d q+r+x}{x} ; \quad \frac{a+r+x}{x}=\frac{p}{x} \pitchfork q$.

The reduced job security associated with increased competition rises the wage paid by (potentially) ..ring ..rms relative to the wage paid by (potentially) hiring ..rms. A similar result can al so be established concerning the hiring rate.

P roposition 6 An increase in ' raises the probability of ..nding a job when unemployed.

Proof. We already know that the solution for $a^{a}$ is identi..ed by the value of

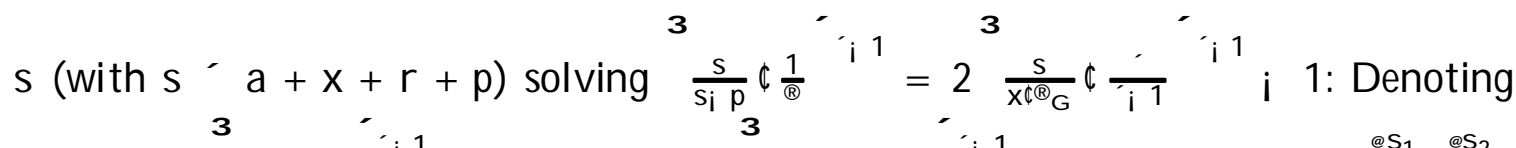

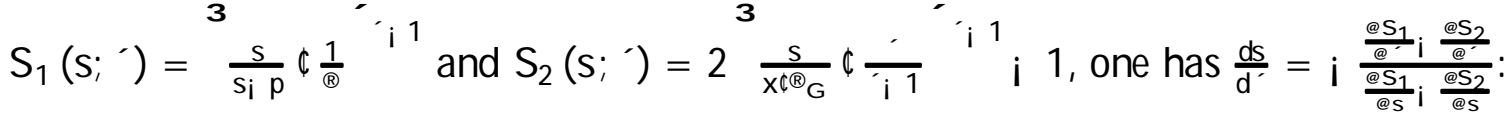
From the price setting equations we know that $\frac{s}{s_{i} p} \Phi \frac{1}{B}<1$ and $\frac{s}{x \notin B_{G}} \phi \frac{1}{i_{1}}<1$. It can easily be shown that $\frac{\Phi_{1}}{\Theta_{S}}<0$ and $\frac{\Phi_{2}}{\Theta_{8}}>0$ : The sign of $\frac{d s}{d}$ thus depends on the sign of $\frac{\Phi_{1}}{\Phi} \mathrm{i} \frac{\Phi_{2}}{\Phi}$ which can be shown to be positive. In fact, one can see that both $\mathrm{S}_{1}\left(\mathrm{~s}^{\prime}{ }^{\prime}\right)$ and $\mathrm{S}_{2}\left(\mathrm{~s} ;{ }^{\prime}\right)$ are monotonically decreasing functions of ' (that is, $\frac{\Phi_{1}}{\varrho}<0$ and $\left.\frac{\Phi_{2}}{\varrho}<0\right)$; moreover $S_{1}(s ; 1)=0>i 1=S_{2}(s ; 1)$. Therefore, for the two curves to cross and de. ne a positive integral $s\left({ }^{\prime}\right)$ the following condition must hold: $\frac{\Phi_{1}}{\Phi}>\frac{\Phi_{2}}{\Phi}$ : One can also see this from the ..gure below. 


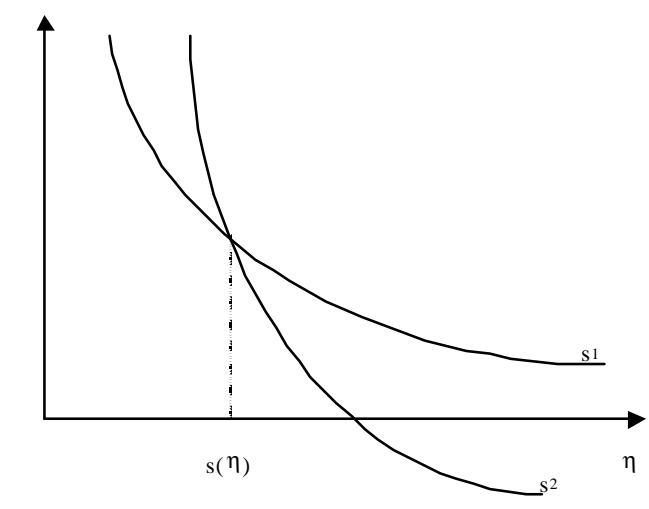

Figure 2. De..ning $s\left({ }^{\prime}\right)$

These results establish a strict correlation between the structures of product and labour markets as measured respectively by the intensity of competition and of turnover. The rationale for these results is the following. First one should note that, as the ratio of the intermediate goods' prices $\frac{P_{B}}{P_{G}}$ is a function of relative employment I, an increase in the intensity of competition ' tends to compress relative prices and therefore pushes relative employment I up for any given level of wages. This modi..cation of relative and absolute prices requires also an adjustment of wage levels, which is done through a change in the endogenous hiring rate a: in order for the el ciency wages to keep up with price increase, the hiring rate has to increase.

If we now go back to the łow equilibrium condition (17) we can easily deduce the expressions of aggregate and sectorial employment levels as functions of a and I. Hence, the results on the separation and hiring rate taken together lead us to the following corollary.

Corollary 7 More competitive product markets are associated with more de facto ‡exible labour markets; for a given size of shocks, the adjustments in the level of 
employment are larger when product market competition is stronger

Proof. Employment adjustments are then given by $\phi L=\frac{L_{G} L_{B}}{2}=\frac{a d\left(l_{i} 1\right) \mathbb{N}}{a(1+1)+\left(i_{i} 1\right) \phi}$ :

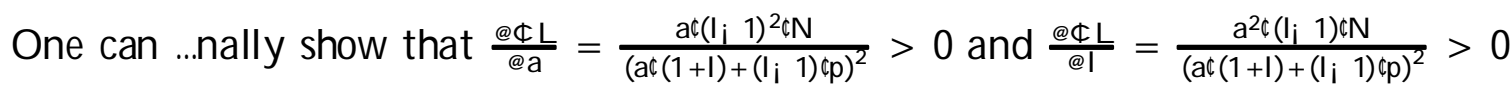

This result contradicts the common view according to which more competition, associated with larger price adjustments, should lead to smaller quantity adjustments. What distinguishes our result from this standard view is the wage-setting process. $\mathrm{E} ф$ ciency wage requirements prevent large real wages adjustments, which would not respect the incentive compatibility constraint for workers. As a result, the only adjustment variables left are quantities.

We may now establish the result concerning the exects of increased product market competition on the level of unemployment. In fact, if we now go back to the ‡ow equilibrium condition (17) we can easily deduce that $L=\frac{a d(1+1) \mathbb{N}}{a(q+1)+\left(I_{i} 1\right) \Phi^{\prime}}$, which allows us to de.ne employment as a function of a and I. O ne can intuitively see that the combination of higher hiring and separation rate determined by increased competition may call for a adverse compensation in terms of the employment levels. In fact, two opposite forces are at work as it is formally established below.

P roposition 8 Increased competition on the product market leads to a decrease in total employment if

$$
\frac{L_{s}}{i L} \Phi s^{\not a}<1
$$

with $s^{a x}=a^{a}+p+x+r$

Proof. We can substitute $I_{1}\left(a ;{ }^{\prime}\right)$ for I into the expression of total employment. 


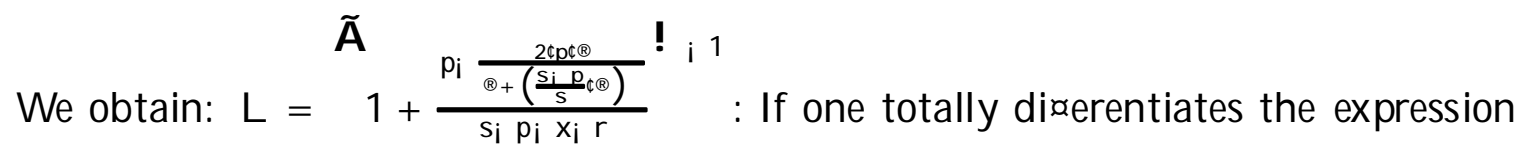
for employment, one has:

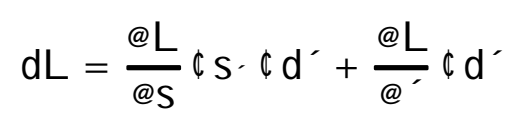

R earranging gives:

$$
\frac{d L}{d^{\prime}}=L_{s} \phi s^{\prime}+L^{\prime}
$$

where $L_{x}$ is $\frac{d^{Q}}{\varrho}$. We know that $S^{\prime}>0$; it can be show that $L^{\prime}<0$ : The expressions for the partial derivatives of $L$ can be computed:

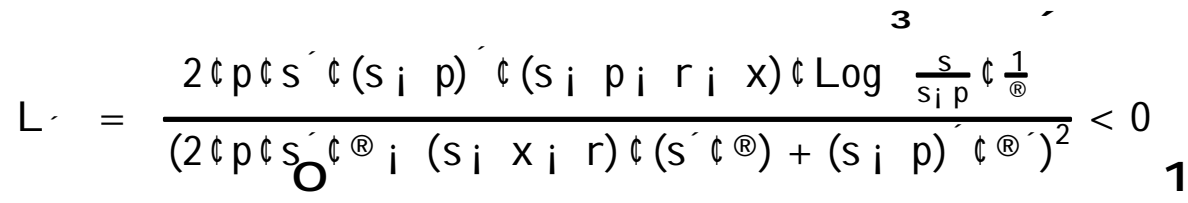

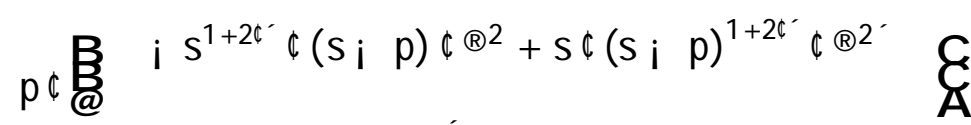

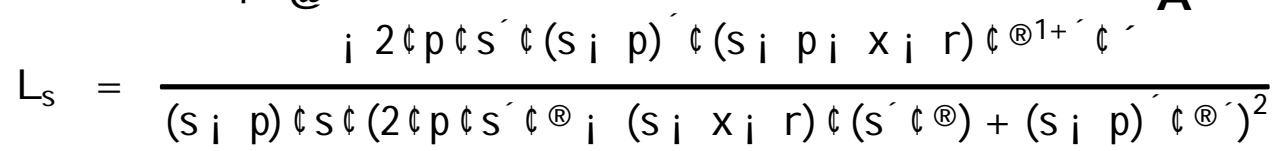

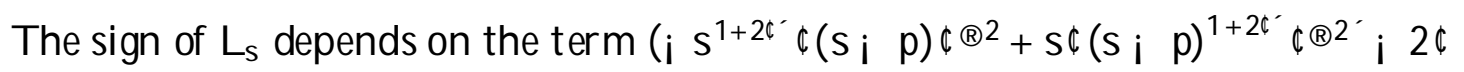
$p \notin s^{\prime} \phi(s \text { i } p)^{\prime} \phi(s$ i $p$ i $x$ i $\left.r) \phi \mathbb{Q}^{1++^{\prime}} \phi^{\prime}\right)$ ? 0 . Rearranging one has: $2 \phi p \phi^{\prime} 7 \mathrm{~T}\left(s_{;^{\prime}}\right)=$ $s \notin(s i \quad p) \notin \frac{\left(\frac{s}{s_{i} p}\right)^{\prime} \Phi^{\prime} \otimes_{i} i_{i}\left(\frac{1}{\Theta}\right)^{\prime i 1}}{s_{i} p_{i} x_{i} r}>0$. The sign of $L_{s}$ is thus hard to determine. We can nevertheless conclude that $\frac{d L}{d^{\prime}}<0$ if $L_{s} \$^{\prime}+L,<0$ which immediately leads to the condition stated in the proposition.

To sum up, the above proposition shows that the exects on employment of increased competition are basically of two sorts. First, one can recognize a 'traditional' positive exect that can be associated to reduced market imperfection and better 
employment opportunities: this translates in our model through the positive exect of increased hiring opportunities on employment. However, a second mechanism is present in our model which works through the wage setting process, particularly the eł ciency wage formation. Increased competition generates larger separations which generates an direct negative impact of competition on aggregate employment.

A second result is immediately linked to the previous one. De. ning the relative wage $W^{R}=\frac{w^{G}}{W^{B}}$, one can establish the following proposition.

P roposition 9 Increased competition on the product market rises relative wages if

$$
\frac{i W_{s}^{R}}{W^{R}} \phi s^{\prime}<1
$$

Proof. We can substitute $I_{1}\left(a ;{ }^{\prime}\right)$ for $q$ into the expression of relative wages

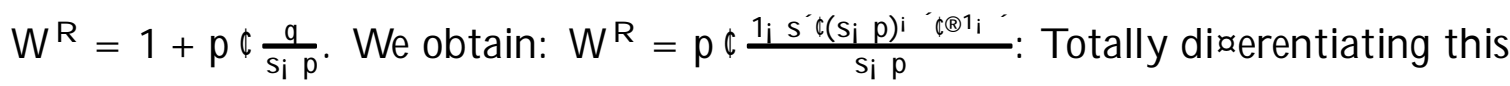
expression gives:

$$
d W^{R}=\frac{@ W^{R}}{@ s} \phi s^{\prime} \phi d^{\prime}+\frac{@ W^{R}}{@^{\prime}} \phi d^{\prime}
$$

R earranging gives:

$$
\frac{d W^{R}}{d^{\prime}}=W_{s}^{R} \phi s^{\prime}+W^{R}
$$

where $W_{x}^{R}$ is $\frac{G N^{R}}{\varrho}$. We know that $s^{\prime}>0$; it can be show that $W^{R}>0$ :

The expressions for the partial derivatives of $L$ can be computed:

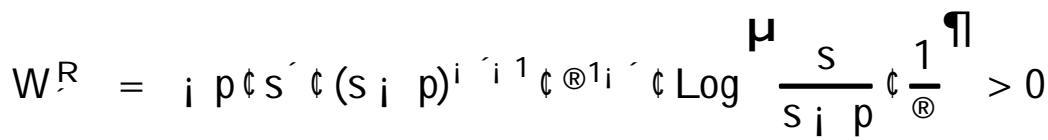

$$
\begin{aligned}
& W_{s}^{R}=p q \frac{i s+s^{\prime} \phi(s i p)^{i^{\prime}} \phi \otimes^{I_{i}^{\prime}} \phi\left(s+p \phi^{\prime}\right)}{(s ; p)^{2} \phi s}
\end{aligned}
$$


The sign of $W_{s}^{R}$ is determined by $i s+s^{\prime} \phi(s ; p)^{i}\left(Q^{l_{i}^{\prime}} \phi\left(s+p \phi^{\prime}\right)\right.$ ? 0 . Rearranging, one obtains: $s^{\prime} i^{1} \phi(s \text { i } p)^{i^{\prime}} \phi \otimes^{T_{i}^{\prime}} \phi\left(s+p \phi^{\prime}\right)$ ? 1. One can see that: $s^{\prime} i{ }^{1} \phi(s \text { i } p)^{i^{\prime}} \phi$

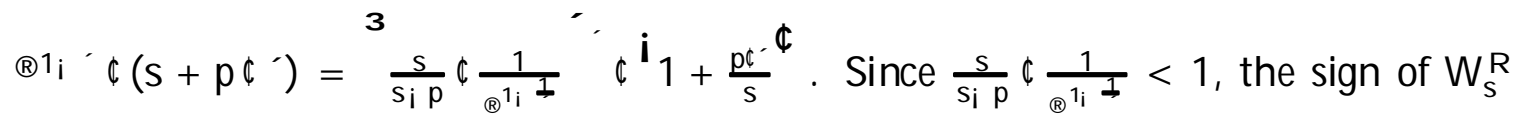
is hard to determine. However, one can see that $\frac{d W^{R}}{d}>0$ if $\frac{W^{R} W^{\prime}}{W^{R}}>i 1$ which immediately leads to the condition stated above.

A complete characterisation of the possible cases where the conditions above are met would be extremely diф cult to undertake. An example is however presented in A ppendix 1, where a simulation is proposed showing that increased competition indeed has a negative impact on employment and widens the wage ratio.

\section{Conclusion}

According to conventional wisdom, increased competition on product markets would unambiguously contribute to alleviating the burden of adjustment which falls on imperfect labour markets when shocks occur. The model presented above suggests that this assertion needs to be carefully quali..ed. The adverse exects of el ciency wage rigi dities on the labour market may indeed be worsened by an increase in product market competition, when the impact on endogenous labour markets łows is taken into account.

In fact, endogenous workers łows are generated through ..rms adjusting to shocks through either quantities or price(wage) adjustments; employment dixer entials across ..rms hit by either bad or good shocks endogenously determine the hiring and ..ring rates, i.e. workers turnover which in turn positively axect the level of the ed ciency 
wages.

As in standard imperfect competition models, increased competition will push up labour demand and squeeze price dixerentials across ..rms in either a good or bad state. In other words, increased competition reduces the extent to which ..rms can use price variations to adjust to shocks. As a consequence, in the absence of appropriate relative real wages adjustments, employment variation across ..rms would become stronger, for any given size of shocks. In our model, it is the presence of ec ciency wage rigidities that induce stronger variations of employment as a response to given shocks, as competition increases on the product market. In fact, widening employment adjustments (following increased competition) generate increased eф ciency wage premia by pushing the separation and hiring rates up.

This shows that more competition means more turnover on the labour market, which may indeed make the burden of adjustments that falls on employment heavier. Depending on the relative elasticities of the separation and hiring rates to an increase in competition, this may ultimately lead to rising relative wages and aggregate employment losses.

To conclude one should stress that, this result being driven by an eф ciency wage mechanism, it does apply even in the absence of any direct regulation on the labour market. This tells us that even coordinated labour market and product market reforms may lead to perverse outcomes if the additional hidden source of rigidities generated by eфc ciency wage mechanisms is overlooked ${ }^{17}$.

\footnotetext{
${ }^{17} \mathrm{~T}$ his point relates directly to the issue of policy complementarities discussed in recent contributions such as in particular, Snower and O rszag [1998] and Snower and Coe [1997].
} 


\section{R eferences}

[1] A kerlof G. and Yellen J . [1990] The fair-wage exort hypothesis and unemployment. Quarterly J ournal of Economics. 105, 255-283.

[2] A ndersen T.M ., Haldrup N. and Sørensen J .R. [2000] Labour markets and international integration. Paper presented at ESSLE, A mmersee, September.

[3] Bertola G. [1990] ] ob security, employment and wages. European E conomic Review 34, 851-886.

[4] Bertola G. and Ichino A. [1995] Wage Inequality and U nemployment: United States vs. Europe. In: Bernanke B. and Rotemberg J. (Eds) NBER Macroeconomics Annual 1995.

[5] Bertola G. and R ogerson R. [1997] Institutions and labor reallocation. European E conomic Review 41, 1147-1171.

[6] Boeri T., Nicoletti G. and Scarpetta S. [2000] Regulation and labour market performance CEPR Discussion Paper No. 2420, April.

[7] Burda M . C. [2000] Product market regulation and lab our market outcomes: how can deregulation create jobs? CE Sifo Working Paper Series N o. 230, J anuary.

[8] Burda M. C. and Wyplosz C. [1994] Gross worker and job ‡ows in Europe. European Economic Review, 38, 1287-1315.

[9] Fella G. [2000] E ф ciency wage and eф cient redundancy pay, European E conomic Review, 44, 1473-1491. 
[10] Gersbach H. [2000] Promoting Product M arket Competition to R educe Unemployment in Europe: An Alternative Approach?. K yklos, 53(2), 117-133.

[11] Gersbach H. [1999] Product Market Competition, Unemployment and Income Disparities. Weltwirtschaftliches Archiv, 135(2), 221-240.

[12] Layard R., Nickell S. and J ackman R. [1991] Unemployment. Oxford: Oxford University P ress.

[13] Lazear E. P. [1990] J ob security provisions and employment. Quaterly J ournal of Economics, 105, 699-726.

[14] Lebow D.E. [1992] Imperfect Competition and Business Cycles: An Empirical Investigation. Economic Enquiry 30, 177-193.

[15] Nickell S. [1999] Product markets and labour markets. Labour E conomics, 6(1), $1-20$.

[16] Nickell S. [1997] Unemployment and Labour Market Rigidities: Europe versus North A merica. J ournal of Economic Perspectives, 11(3) 55-74.

[17] Nickell S., Vainiomaki J . and Wadhwani S. [1994] Wages and product market power. E conomica, 61, 457-473.

[18] Nicoletti G., Haxner R.C.G., S. Nickell, S. Scarpetta and G. Zoega [2000] European Integration, Liberalisation and labor Market Performance. In: Bertola G., T. Boeri and G. Nicoletti (Eds) W elfare and Employment in a United Europe. MIT Press. 
[19] OECD [1994] J obs Strategy, Paris: OECD.

[20] OECD [1997] Employment Outlook. Paris: OECD.

[21] Saint-Paul G. [1996] Dual Labor Markets. Cambridge: MIT Press.

[22] Shapiro C . and Stiglitz ] . [1984] E quilibrium unemployment as a worker discipline device. American E conomic Review. 74, 433-444.

[23] Siebert H. [1997] Labor Market Rigidities: At the R oot of Unemployment in Europe. J ournal of Economic Perspectives 11(3), 37-54.

[24] Snower D. and Coe D.T . [1997] Policy Complementarities: the Case for Fundamental Labour Market Reforms, CEPR Discussion Paper No. 1585, February.

[25] Snower D. and Diaz-Vazquez M. P. [1996] E mployment, Macroeconomic F luctuations and J ob Security. CEPR Discussion Paper No. 1430, J uly.

[26] Snower D. and Orszag M. [1998] Anatomy of Policy Complementarity, CEPR Discussion Paper No. 1963, December.

[27] Solow R. [1979] A nother possible source of wage rigidity. J ournal of Macroeconomics $1(1), 79-82$.

[28] Weiss C. [1998] Is Imperfect Competition in the Product Market Relevant for labor Markets? Labour, 12(3), 451-471. 


\section{A Appendix 1: an example of negative impact of increased competition on employment and wages}

To run the simulations we solve for an explicit value of ax by linearizing $\frac{s}{s_{i} p} \phi \frac{1}{\Theta}{ }^{\prime} i 1=$

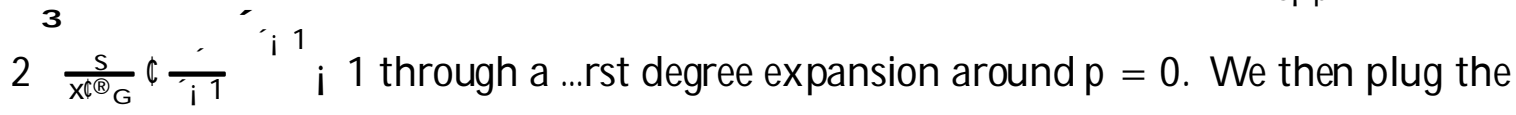
value of ax into $I_{1}\left(a ;{ }^{\prime}\right)$ to obtain $I x$ : The simulations that follow use the following parameters values: $\left[=1, p=0: 03, x=0: 4, r=0: 1, \pm=0: 043,{ }_{B}=1: 6 i \quad \pm\right.$ $\mathbb{R}_{G}=1: 6+ \pm$ Results are presented below. The variable ' $>1$ appears on the horizontal axis in all ..gures. One should further note that by increasing the productivity dixerential \pm (given all other parameters values) the sign of the exect of increased competition on aggregate employment and relatives wages changes as show $n$ in ..gures 6 and 7.

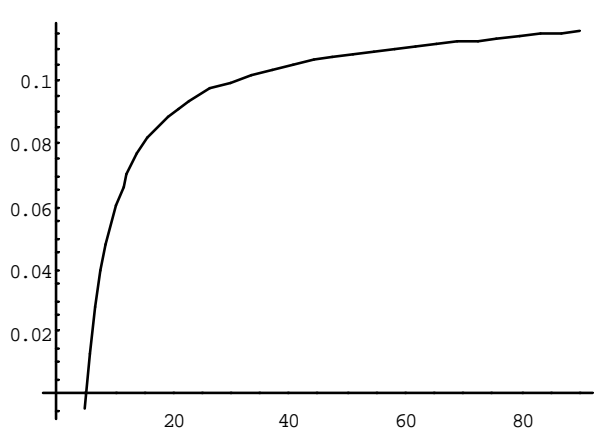

Figure 2. Hiring rate

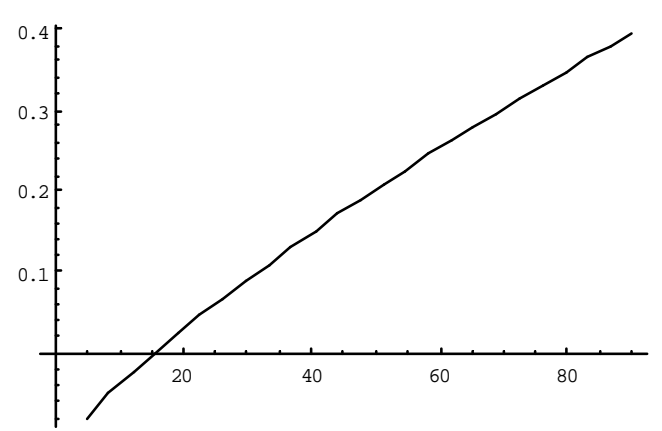

Figure 3. Separation rate 

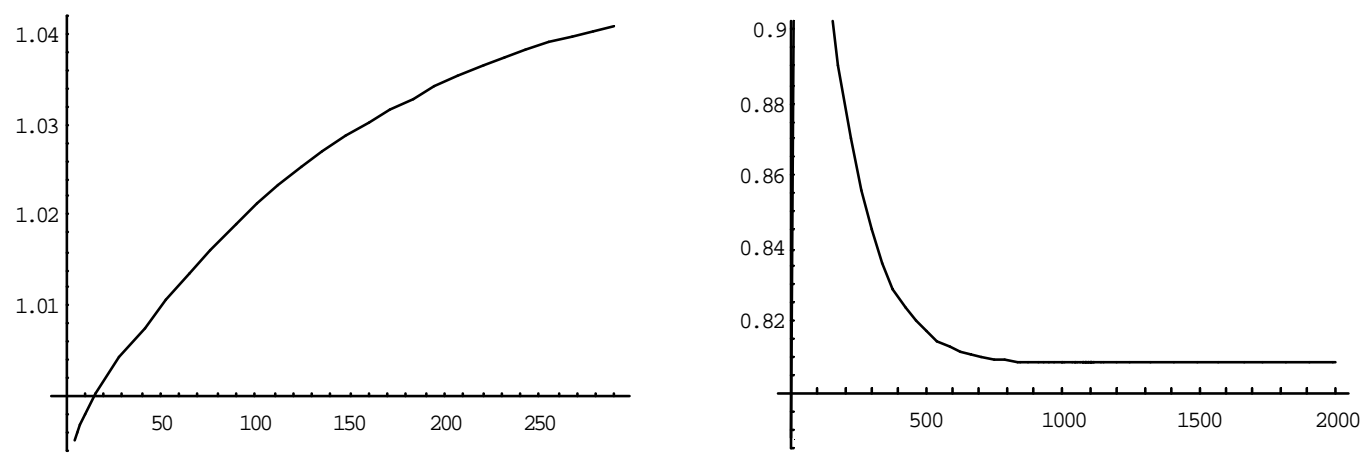

Figure 4. Relative wages with low \pm F igure 5.Total employment with low \pm
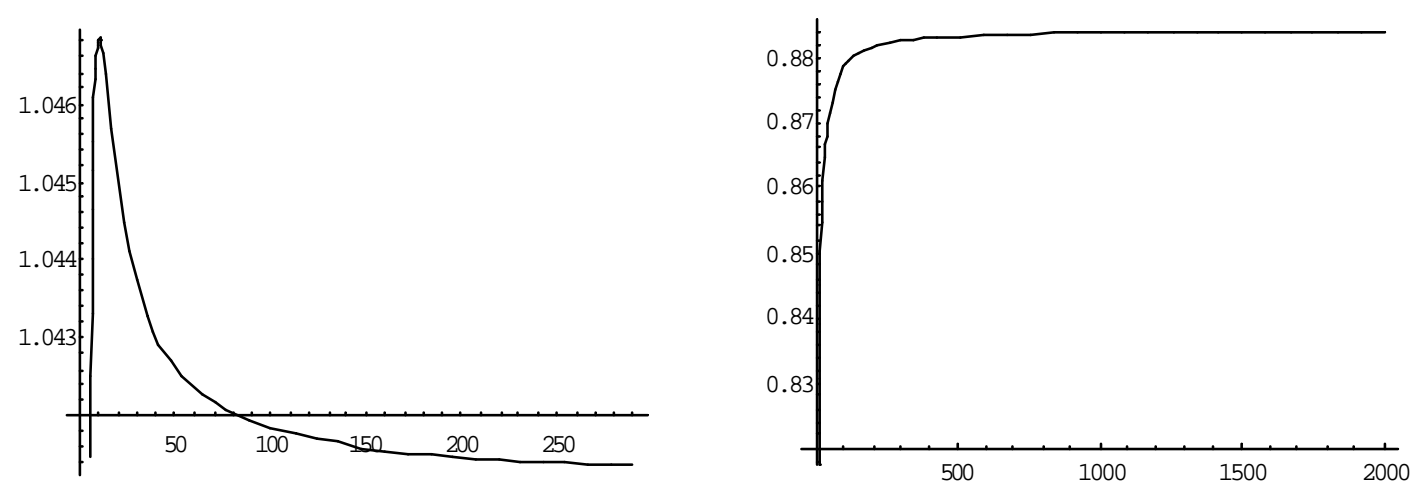

Figure 6. Relative wages with high \pm Figure 7. Total employment with high \pm 


\section{IZA Discussion Papers}

\section{No Author(s)}

191 G. C. Giannelli

C. Monfardini

192

G. Brunello

193

A. Kunze

194

A. Newell

F. Pastore

195

F. Büchel

A. Mertens

196 J. S. Earle

K. Z. Sabirianova

197

G. A. Pfann

198 M. Kreyenfeld

C. K. Spiess

G. G. Wagner

199 H. Entorf

200

T. Bauer

G. S. Epstein

I. N. Gang

201

T. J. Dohmen

G. A. Pfann

202

P. Francois

J. C. van Ours

203 J. M. Abowd

F. Kramarz

D. N. Margolis

T. Philippon

204

G. S. Epstein
Titel

Area

Date

Joint Decisions on Household Membership and Human Capital Accumulation of Youths: The role of 5 $8 / 00$ expected earnings and local markets

Absolute Risk Aversion and the Returns to

5

$8 / 00$

Education

The Determination of Wages and the Gender

Wage Gap: A Survey

5

$8 / 00$

Regional Unemployment and Industrial

Restructuring in Poland

4

$8 / 00$

Overeducation, Undereducation, and the Theory

of Career Mobility

Equilibrium Wage Arrears: A Theoretical and 4

Empirical Analysis of Institutional Lock-In

Options to Quit

$9 / 00$

A Forgotten Issue: Distributional Effects of Day

3

$9 / 00$

Care Subsidies in Germany

Rational Migration Policy Should Tolerate Non-

Zero Illegal Migration Flows: Lessons from

Modelling the Market for Illegal Migration

What are Migration Networks?

$9 / 00$

Worker Separations in a Nonstationary Corporate 1 Environment

$9 / 00$

Gender Wage Differentials in a Competitive Labor 5

$9 / 00$

Market: The Household Interaction Effect

The Tail of Two Countries: Minimum Wages and 5 Employment in France and the United States

$9 / 00$ Labor Market Interactions Between Legal and
Illegal Immigrants

Temporary Jobs: Stepping Stones or Dead Ends? 1
$10 / 00$

$10 / 00$

M. Francesconi

J. Frank 
206 C. M. Schmidt

R. Baltussen

R. Sauerborn

207

C. M. Schmidt

208

J. Hartog

R. Winkelmann

209 M. Barbie

M. Hagedorn

A. Kaul

210 T. J. Dohmen

211 A. van Soest

M. Das

X. Gong

212 X. Gong

A. van Soest

P. Zhang

213 X. Gong

A. van Soest

E. Villagomez

214 X. Gong

A. van Soest

215 J. Ermisch

M. Francesconi

216 F. Büchel

217 J. Hansen

R. Wahlberg

218 C. Dustmann

A. van Soest

219 F. Kramarz

T. Philippon

220 W. A. Cornelius

E. A. Marcelli
The Evaluation of Community-Based Interventions: Group-Randomization, Limits and Alternatives

Arbeitsmarktpolitische Maßnahmen und ihre

Dutch Migrants in New Zealand:

$10 / 00$

Did they Fare Well?

Dynamic Effciency and Pareto Optimality in a

3

$10 / 00$

Stochastic OLG Model with Production and Social

Security

Housing, Mobility and Unemployment

$11 / 00$

A Structural Labour Supply Model with

5

$11 / 00$

Nonparametric Preferences

Sexual Bias and Household Consumption: A

5

$11 / 00$

Semiparametric Analysis of Engel Curves in Rural China

Mobility in the Urban Labor Market: A Panel Data Analysis for Mexico

Family Structure and Female Labour Supply in Mexico City

The Effect of Parents' Employment on Children's

5

$11 / 00$

Educational Attainment

The Effects of Overeducation on Productivity in

5

$11 / 00$

Germany - The Firms' Viewpoint

Occupational Gender Composition and

Wages in Sweden

5

Parametric and Semiparametric Estimation in

$11 / 00$ Models with Misclassified Categorical Dependent Variables

The Impact of Differential Payroll Tax Subsidies on Minimum Wage Employment

The Changing Profile of Mexican Migrants to the United States: New Evidence from California and Mexico 

former Soviet Union to Israel: Who is coming when? and Earnings: An Empirical Study for Portugal Selection

234 R. Rotte M. Steininger

Sozioökonomische Determinanten extremistischer 3 Wahlerfolge in Deutschland: Das Beispiel der Europawahlen 1994 und 1999 
236 R. Hujer

M. Caliendo

237 S. Klasen

I. Woolard

238 R. Euwals

A. Börsch-Supan

A. Eymann

239 F. Andersson

K. A. Konrad

240 W. Koeniger

241 W. Koeniger

242 G. Faggio

J. Konings

243 E. Brainerd

244 S. M. Fuess, Jr. M. Millea

245 F. Andersson

K. A. Konrad

246 E. Plug W. Vijverberg

247 E. Plug W. Vijverberg

248 P. M. Picard

E. Toulemonde

249 B. M. S. van Praag

P. Cardoso

250 T. J. Hatton

J. G. Williamson
Evaluation of Active Labour Market Policy:

Methodological Concepts and Empirical

Estimates

Surviving Unemployment without State Support: 3

$12 / 00$

Unemployment and Household Formation in

South Africa

The Saving Behaviour of Two Person House-

5

$12 / 00$

holds: Evidence from Dutch Panel Data

Human Capital Investment and Globalization in

5

$01 / 01$

Extortionary States

Labor and Financial Market Interactions: The Case of Labor Income Risk and Car Insurance in the UK 1969-95

Trade, Labor Market Rigidities, and GovernmentFinanced Technological Change

Job Creation, Job Destruction and Employment Growth in Transition Countries in the 90's

4

Economic Reform and Mortality in the Former

4 Soviet Union: A Study of the Suicide Epidemic in the 1990s

Pay and Productivity in a Corporatist Economy:

5

01/01

Evidence from Austria

Globalization and Human Capital Formation

5

$01 / 01$

Schooling, Family Background, and Adoption:

5

01/01

Does Family Income Matter?

Schooling, Family Background, and Adoption:

5

$01 / 01$

Is it Nature or is it Nurture?

The Impact of Labor Markets on Emergence and 2

$01 / 01$

Persistence of Regional Asymmetries

"Should I Pay for You or for Myself?"

3

$01 / 01$

The Optimal Level and Composition of

Retirement Benefit Systems

Demographic and Economic Pressure on

Emigration out of Africa 
254 H. Gersbach

A. Schniewind

255 H. Gersbach

A. Schniewind

Learning of General Equilibrium Effects and the

The Times They Are A-Changin': 
